\title{
Commentary: Cerebral protection during pediatric circulatory arrest, from bench to bedside
}

\author{
Patrick O. Myers, MD
}

\author{
From the Department of Cardiac Surgery, CHUV, Lausanne, Switzerland. \\ Disclosures: Author has nothing to disclose with regard to commercial support. \\ Received for publication March 29, 2019; accepted for publication March 30, 2019; available ahead of print May \\ $21,2019$. \\ Address for reprints: Patrick O. Myers, MD, Division of Cardiac Surgery, CHUV-Centre Hospitalier Universi- \\ taire Vaudois, 46 Rue du Bugnon, 1011 Lausanne, Switzerland (E-mail: patrick.myers@chuv.ch). \\ J Thorac Cardiovasc Surg 2019;158:891-2 \\ $0022-5223 / \$ 36.00$ \\ Copyright (C) 2019 by The American Association for Thoracic Surgery \\ https://doi.org/10.1016/j.jtcvs.2019.03.116
}

In their investigation reported in this issue of the Journal, $\mathrm{Tu}$ and colleagues ${ }^{1}$ studied the transcriptional changes in an animal model of neonatal deep hypothermic circulatory arrest (DHCA). ${ }^{1}$ This contribution provides insights into the mechanisms of neurologic injury during DHCA and areas to develop therapeutic interventions.

Increasing data suggest that DHCA is associated with poor neurodevelopmental outcomes, particularly when it extends beyond 41 minutes, 2,3 as the onus shifts from survival to long-term quality of life in the repair of complex congenital defects. Strategies to minimize the impact of DHCA continue to be studied. Antegrade cerebral perfusion was introduced to maintain brain oxygen delivery during neonatal arch surgery, ${ }^{4,5,6}$ providing more time for the surgeon to perform an optimal repair while minimizing neurologic injury.

The mechanisms of injury during DHCA are complex. Apoptosis plays a crucial role in neuronal cell death after DHCA. ${ }^{7}$ The process starts within a few hours after reperfusion and continues for several days. Ischemia has also been linked to excessive neuronal stimulation and hyperactivity, initiating a cascade leading to neuronal cell death through excitotoxic overstimulation, mainly by glutamate. ${ }^{8}$ The neonatal brain is particularly at risk and does not appear to be uniformly hurt during DHCA; the neocortex, hippocampus, and striatum are more vulnerable. 9,10

$\mathrm{Tu}$ and colleagues ${ }^{1}$ found that 124 genes were upregulated, while 74 genes were downregulated, in the striata of newborn piglets subjected to 2 hours of cardiopulmonary bypass, 30 minutes of $\mathrm{DHCA}$ at $18^{\circ} \mathrm{C}$, and 6 hours of recovery. Inflammatory signaling was the strongest response, with upregulation of chemokine ligands CXCL10, CXCL9, and CCL2 relative to sham controls. These could play a role in recruiting inflammatory cells and further brain damage in the later stages.

$\mathrm{Tu}$ and colleagues ${ }^{1}$ also found that nuclear factor $\kappa \mathrm{B}$ $(\mathrm{NF}-\kappa \mathrm{B})$ binding sites were prominently enriched in the strategy.

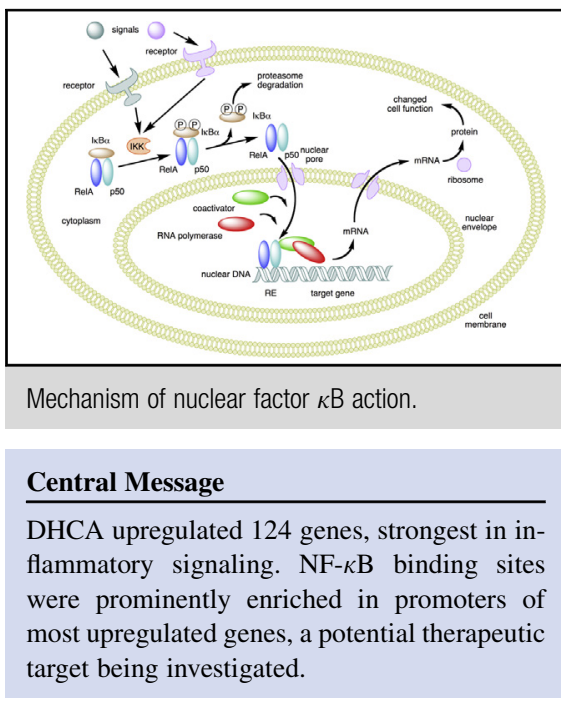

See Article page 882 .

promoters of close to two-thirds of the upregulated genes. $\mathrm{NK}-\kappa \mathrm{B}$ is a powerful transcription factor family that controls expression of cytokines, chemokines, and cell survival proteins in response to stress (Figure 1). Multiple pharmacologic agents inhibiting $\mathrm{NF}-\kappa \mathrm{B}$ signaling are being investigated in cancer ${ }^{11}$ and stroke ${ }^{12,13}$ treatment, and NF- $\kappa \mathrm{B}$ inhibition may be of interest to avoid neurologic injury in DHCA by limiting apoptosis and inflammation.

This study has limitations that invite further investigation: the sham controls did not undergo cardiopulmonary bypass, making it difficult to understand whether gene upregulation or downregulation was a response to DHCA and cardiopulmonary bypass or just cardiopulmonary bypass. Tu and colleagues ${ }^{1}$ chose one duration of DHCA and early time point, in the hopes of identifying genes upregulated early after DHCA that may have a major downstream impact. It would be interesting to understand how these changes in transcription vary with duration of DHCA or over time, providing windows of opportunity for intervention. Furthermore, operations performed with DHCA have become less frequent, with 59\% of patients undergoing arch repair having antegrade cerebral perfusion and only $32 \%$ having DHCA in a recent review of the STS Congenital Database. ${ }^{14}$ The variations in transcriptome need to be confirmed in this perfusion 


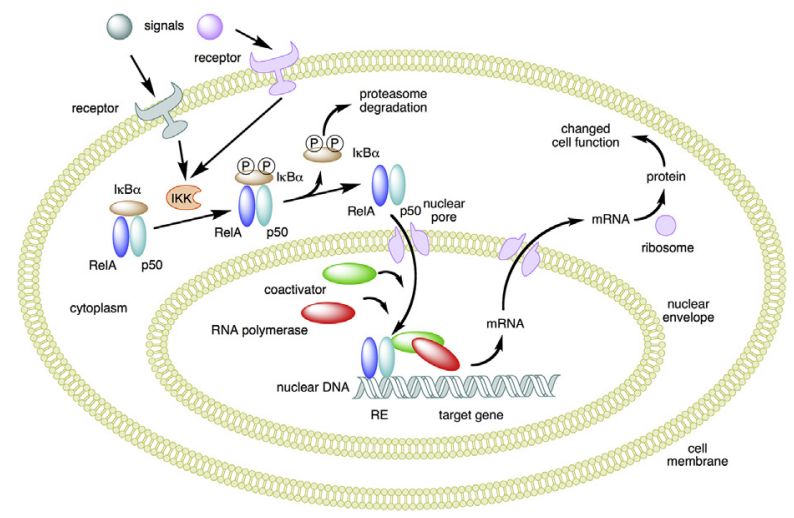

FIGURE 1. Mechanism of nuclear factor $\kappa \mathrm{B}(\mathrm{NF}-\kappa \mathrm{B})$ action. The NF- $\kappa \mathrm{B}$ heterodimer consists of Rel and p50 proteins as an example. Extracellular signals activate $\mathrm{I} \kappa \mathrm{B}$ kinase (IKK), which phosphorylates $\mathrm{I} \kappa \mathrm{B} \alpha$. This results in ubiquitination, dissociation of $\mathrm{I} \kappa \mathrm{B} \alpha$ from NF- $\kappa \mathrm{B}$. The activated NF- $\kappa \mathrm{B}$ is translocated into the nucleus, where it binds to specific sequences of DNA. The DNA/NF- $\kappa$ B complex then recruits other proteins, such as coactivators and RNA polymerase, which transcribe downstream DNA into messenger RNA (mRNA). (Reproduced from Boghog2 under Creative Commons license, http://en.wikipedia.org/w/index.php?title=Image \%3ANFKB_ mechanism_of_action.png.)

$\mathrm{Tu}$ and colleagues ${ }^{1}$ deposited their genomics data in Gene Expression Omnibus (GEO, https://www.ncbi.nlm. nih.gov/geo/), which is open for public review. This is an excellent practice, for which they are to be commended.

\section{References}

1. Tu LN, Timms AE, Kibiryeva N, Bittel D, Pastuszko A, Nigam V, et al. Transcriptome profiling reveals activation of inflammation and apoptosis in the neonatal striatum after deep hypothermic circulatory arrest. J Thorac Cardiovasc Surg. 2019;158:882-90.e4.

2. Newburger JW, Jonas RA, Wernovsky G, Wypij D, Hickey PR, Kuban KC, et al. A comparison of the perioperative neurologic effects of hypothermic circulatory arrest versus low-flow cardiopulmonary bypass in infant heart surgery. $N$ Engl J Med. 1993;329:1057-64.

3. Robson VK, Stopp C, Wypij D, Dunbar-Masterson C, Bellinger DC, DeMaso DR, et al. Longitudinal associations between neurodevelopment and psychosocial health status in patients with repaired D-transposition of the great arteries. J Pediatr. 2019;204:38-45.e1.

4. Pigula FA, Siewers RD, Nemoto EM. Regional perfusion of the brain during neonatal aortic arch reconstruction. J Thorac Cardiovasc Surg. 1999;117: 1023-4.

5. Pigula FA, Nemoto EM, Griffith BP, Siewers RD. Regional low-flow perfusion provides cerebral circulatory support during neonatal aortic arch reconstruction. J Thorac Cardiovasc Surg. 2000;119:331-9.

6. Pigula FA, Gandhi SK, Siewers RD, Davis PJ, Webber SA, Nemoto EM. Regional low-flow perfusion provides somatic circulatory support during neonatal aortic arch surgery. Ann Thorac Surg. 2001;72:401-6; discussion 406-7.

7. Ditsworth D, Priestley MA, Loepke AW, Ramamoorthy C, McCann J, Staple L, et al. Apoptotic neuronal death following deep hypothermic circulatory arrest in piglets. Anesthesiology. 2003;98:1119-27.

8. Amir G, Ramamoorthy C, Riemer RK, Reddy VM, Hanley FL. Neonatal brain protection and deep hypothermic circulatory arrest: pathophysiology of ischemic neuronal injury and protective strategies. Ann Thorac Surg. 2005;80:1955-64.

9. Pastuszko P, Schears GJ, Greeley WJ, Kubin J, Wilson DF, Pastuszko A. Granulocyte colony stimulating factor reduces brain injury in a cardiopulmonary bypass-circulatory arrest model of ischemia in a newborn piglet. Neurochem Res. 2014;39:2085-92.

10. Pastuszko P, Schears GJ, Pirzadeh A, Kubin J, Greeley WJ, Wilson DF, et al. Effect of granulocyte-colony stimulating factor on expression of selected proteins involved in regulation of apoptosis in the brain of newborn piglets after cardiopulmonary bypass and deep hypothermic circulatory arrest. J Thorac Cardiovasc Surg. 2012;143:1436-42.

11. Ambrosini G, Do C, Tycko B, Realubit RB, Karan C, Musi E, et al. Inhibition of NF- $\kappa \mathrm{B}$-dependent signaling enhances sensitivity and overcomes resistance to BET inhibition in uveal melanoma. Cancer Res. 2019;79: 2415-25.

12. Yen T-L, Thomas P-A, Yang C-H, Sheu J-R, Hsu C-Y, Jayakumar T. Multi-targeting andrographolide, a novel NF- $\kappa \mathrm{B}$ inhibitor, as a potential therapeutic agent for stroke. Int J Mol Sci. 2017;18:E1638.

13. Sarnico I, Branca C, Lanzillotta A, Porrini V, Benarese M, Spano PF, et al. NF- $\kappa$ B and epigenetic mechanisms as integrative regulators of brain resilience to anoxic stress. Brain Res. 2012;1476:203-10.

14. Meyer DB, Jacobs JP, Hill K, Wallace AS, Bateson B, Jacobs ML. Variation in perfusion strategies for neonatal and infant aortic arch repair: contemporary practice in the STS Congenital Heart Surgery Database. World J Pediatr Congenit Heart Surg. 2016;7:638-44. 